\title{
Drug TrafFicking in Russia: A Form of Organized CRIME?
}

\section{Letizia PaOLI}

The decade following the breakdown of the Soviet Union has registered a rapid growth of illegal drug use and trade in Russia. Illicit psychoactive substances were consumed even prior 1991, but the former USSR did not participate significantly in the international drug market either as an importer or exporter. This pattern of relative self-sufficiency, however, drastically changed during the 1990s, at the same time as both the Russian drug demand and supply consistently expanded and diversified. If they can afford it, Russia drug users can today buy the same illicit psychoactive drugs that can be found in any Western European or North American city and that are imported from countries as far away as Colombia, Afghanistan and Holland. As a Moscow drug consumer puts it, "over the past ten years drugs have become accessible to whomever wishes to buy them" (Interview H11).

The expansion of the Russian drug market during the 1990s also entailed the emergence of a nationwide drug distribution system, which brings illicit drugs from producers to consumers, and the consolidation of the professional role of the drug dealer. As much as in Western Europe and the USA up to the mid-1970s, the latter role did not exist in Russia up to the early 1990s. In Soviet times there was no nationwide drug distribution system: Soviet drug users largely consumed illegal psychoactive substances that were available in their region and often either harvested or produced the drugs themselves. 
Only with the diversification of drug supply in the 1990s and Russia's entrance into international drug trade did the drug dealer as a professional role emerge to link producers to consumers and to regularly supply large urban centres with a variety of illegal drugs coming from distant regions. Who carries out these intermediary functions in contemporary Russia? Who are the drug traffickers and dealers? How do they operate? Are they organized in large-scale enterprises or are there prevalently small drug dealing groups and single entrepreneurs? To what extent are drug dealing enterprises linked — or indeed superimposed — with organized crime? Is thus drug trafficking to be considered the domain of organized crime, meant as a set of large-scale criminal organizations, or is it merely an organized crime activity which is carried out by a plurality of independent actors?

These are the main questions to which the present article aims to respond. The answers will be largely drawn from a report on illegal drug trade in Russia, which I wrote for the United Nations Office for Drug Control and Crime Prevention (UNODCCP) (see Paoli, 2001a). In the UN-sponsored project, field research was conducted by Russian scientists and outreach workers and by myself in nine cities, including Moscow, St. Petersburg, Krasnoyarsk, and Vladivostok. All in all, 90 indepth interviews with different types of experts and 15 with drug users and dealers were carried out. In co-operation with the Research Institute of the Prosecutor's General Office (RIPGO), the author additionally analyzed a sample of drug-related criminal cases and intelligence documents, which were up until now inaccessible to Western scholars.

\section{Russian Law Enforcement Agencies' Analyses and Statistics}

In official reports, Russian law enforcement authorities present a very "organized" picture of the drug trade. In its latest report on drug and organized crime, for example, the Russian Ministry of the Interior (MVD) categorically states that "drug crime is always organized" and the same view was repeated by several law enforcement officers interviewed in Moscow (Interviews A4 and A7). Furthermore, the MVD proposes a very top-down explanation of the expansion of the Russian drug market. As shown by the following quote, in fact, the latter is linked to the integration of Russian organized crime groups into large international drug cartels:

A considerable part of Russian criminal societies have entered into an alliance with international drug cartels and have become an integral part of them. The consequence of this integration is the rapid growth of drug criminality, which is accompanied by a steady increase of drug users in Russia. Experts believe that nearly 1,600 criminal groups in Russia are engaged in the drug trade, which are composed of at least 6,000 people (MVD, 2000, p. 5). 


\section{Drug Trafficking in Russia}

In their turn, the so-called "criminal societies" are described as follows:

Criminal leaders actively develop united societies. The development of these societies, the management of their finances, and the division of their spheres of influence are carefully planned. These structures have centralized administrations with subordinate units and strict discipline of their members as well as intelligence and counterintelligence, technical maintenance and armed security services. This powerful support enables them to take root practically everywhere and influence important spheres of life in the Russian regions. It can be stated that organized crime dictates the terms of functioning to branches of the economy as well as norms of social behavior to different regions (MVD, 2000, p. 3).

The same "conspiratorial" view is shared by the Federal Security Service (FSB), Russia's main intelligence agency, the former KGB. Talking about drug trade in the Kaliningrad area (a Russian enclave between Lithuania and Poland), for example, the latter agency notes:

The local organized crime groups, which are founded on ethnic ties (such as the Azerbaijani and the gypsies) have steady interregional relations, numerous members, they are well armed, equipped with modern technology and are highly organized. They are integrated into the entrepreneurial activity of commercial structures and companies, have links with corrupt state authorities and the law enforcement, and aspire to monopolize the drug market. The approximate annual turnover of their illegal trafficking is estimated at about 12 tons of drugs (FSB, 2000).

Likewise, according to the same institution, in the Siberian city of Krasnoyarsk,

a precise distribution of roles can be observed in the structure of organized criminal groups involved in drug trafficking, with leaders having contacts to wholesale suppliers in Central Asia and to corrupt officials of law enforcement agencies. These groups consist of several dozen people (FSB, 2000).

The idea that drug trafficking is dominated by large, structured criminal groups finds, however, scarce support even in law enforcement statistical data. As shown by Table 1, in fact, the crimes committed by "organized crime groups" represent less than $1 \%$ of the total drug offences reported in Russia and in 1999 accounted for only $4.1 \%$ of drug trafficking cases. The percentages are somewhat higher, if the crimes committed by "groups" are considered. The latter accounted for $4.7 \%$ of total drug offences in 1999, down from $6.5 \%$ in 1995. Their percentage is higher, if the drug trafficking cases are considered: in 1999, in fact, $23.8 \%$ of drug trafficking offences were committed by a "group". Even this percentage, however, has almost halved since 1995 , when over $45 \%$ of all drug trafficking cases involved a group. 
PAOLI

However, the concept of group criminality is very loosely defined in the Russian criminal code, as two people suffice to build such a group. Article 35, par. 1, in

TABLE 1

Drug Offenses Reported in Russia, Including Those Committed by a Group and an Organized Crime Group 1995-1999

\begin{tabular}{lrrrrr}
\hline & 1995 & 1996 & 1997 & 1998 & 1999 \\
\hline Drug offences (total) & 79,819 & 96,645 & 184,832 & 190,127 & 216,364 \\
Drug trafficking (art. 228, p. & 11,448 & 19,982 & 28,979 & 33,562 & 42,883 \\
2,3,4; art. 234, p. 1,2,3) & & & & & \\
- committed by a group & 5,205 & 6,489 & 7,549 & 6,499 & 10,199 \\
$\quad$ \% of total drug offences & 6.5 & 6.7 & 4.1 & 3.4 & 4.7 \\
$\quad$ \% of drug trafficking cases & 45.5 & 32.5 & 26.0 & 19.4 & 23.8 \\
- committed by an organized & - & 562 & 1.439 & 913 & 1,763 \\
crime group & & & & & \\
$\quad$ \% of total drug offences & - & 0.6 & 0.8 & 0.5 & 0.8 \\
\% of drug trafficking cases & - & 2.8 & 5.0 & 2.7 & 4.1 \\
\hline
\end{tabular}

Source: MVD, 2000: 15.

fact, states: "a crime shall be deemed to be committed by a group of persons, if two or more perpetrators without prior collusion participate in the commission thereof" (Butler, 1997, p. 23). The third paragraph of the same article sets forth the conditions under which a crime is considered committed by an "organized group": "if it is committed by a stable group of persons, who combined beforehand to commit one or several crimes" (Butler, 1997, p. 23). Even in this case no quantitative parameter is set and the only two requirements entail cohesiveness and previous agreement. Even a blood family that deals drugs can thus be considered an organized crime group.

The 10,000 organized crime groups that, according to the MVD, are active in Russia, and the 1,600 of them that are involved in drug trafficking, can therefore be seen in a new perspective. Indeed, given the above definition, it is fair to assume that not all of them are large, highly structured and powerful criminal groups. The latter traits are, in fact, reserved to what the Russian Criminal Code defines as a "criminal society". The fourth paragraph of the already quoted Article 35 states:

A crime shall be deemed to be committed by a criminal society (criminal organization), if it was committed by a cohesive organized group (or organization) created for the commission of grave or especially grave crimes 


\section{Drug Trafficking in Russia}

or by the combining of organized groups created for the same purpose (Butler, 1997, p. 23).

According to the data reported by a high-ranking official of the MVD in September 1999 in a UN-meeting in Vienna, in Russia there are currently 98 such criminal societies, out of which 22 are of most serious concern (Kichanov, 1999). If organized crime is defined as a set of large-scale, stable criminal organizations entailing some sort of internal division of labor, the latter and not the 10,000 figure is the number to be taken into account. Unfortunately, no data are published on the involvement of Russia's 98 "criminal societies" in illicit drug trade.

As the staff of the Research Institute of the Prosecutor General's Office (RIPGO) noted, the analysis of law enforcement statistics leaves us in a "paradoxical situation":

On the one hand, the public opinion's view, which is spread by the mass media, seems to be realistic. Accordingly, the Russian drug mafia is at work, as it results from the mass spread of illegal drug use. Offenders specializing in illegal drug trafficking could have promoted the spread of drug use even to those regions that previously never had had socio-cultural experience with illegal drugs (such as the Northern and Central parts of Russia and Siberia). On the other hand, this activity is not reflected in statistical data, i.e. it does not come to light, is not exposed and is not punished (RIPGO, 2000, p. 59).

\section{Drug Dealing and Trafficking in Selected Criminal Cases}

Neither "criminal societies" nor large-scale organized crime groups emerge from the analysis of the 52 drug-related criminal cases that was carried out by the author together with the staff of the Research Institute of the Prosecutor General's Office (RIPGO) in Moscow. Almost half of the cases analyzed (25) were issued by a criminal court of St. Petersburg, Russia's second largest city; 11 were pronounced by a district court in Krasnodar (a city of 627,000 inhabitants in Southern Russia, close to the Black Sea); nine by a district court in Omsk (1,159,000 inhabitants) in Southwestern Siberia, close to the border with Kazakhstan; five by a district court in Nizhniy Novgorod, Russia's third largest city (formerly Gorky) and one in Moscow. All the cases were issued between December 1997 and December 1999. They were selected by the RIPGO, with the aim to provide a representative picture of drug-related sentencing in Russia in the late 1990s.

Heroin was involved in 22 of the cases examined and most of these (18) were dealt with by a St. Petersburg court (see Table 2). In 13 cases the primary drug was either opium or poppy straw: only one of the these cases was examined by St. Petersburg courts, which instead took care of the only two penal proceedings involving ecstasy and LSD. Cannabis products were seized from the defendants in 16 cases, which were issued either by the courts in St. Petersburg (seven), those in 
PAOLI

Krasnodar (six), or those from Omsk (three). Ephedrine was mentioned in only two of the cases, both of which were issued by the Krasnodar courts. Seized drugs ranged from a few one hundredth of a gram of heroin to 2.5 kilograms of poppy straw. All the 78 defendants were sentenced for the offences they were charged with.

TABLE 2

Selected Criminal Cases, According to the Drug Seized*

\begin{tabular}{lcccccc}
\hline & Heroin & Cannabis & $\begin{array}{c}\text { Opium or } \\
\text { poppystraw }\end{array}$ & Ephedrine & Ecstasy & LSD \\
\hline St. Petersburg & 18 & 7 & 1 & $\cdot$ & 1 & 1 \\
Krasnodar & - & 6 & 3 & 2 & $\cdot$ & - \\
Omsk & 2 & 3 & 5 & $\cdot$ &. &. \\
Nizhniy Novgorod & 2 & - & 4 & - &. &. \\
Moscow & 1 & - & - & - &. & - \\
Total & 23 & 16 & 13 & 2 & 1 & 1 \\
\hline
\end{tabular}

* The sum exceeds 52 because more than one drug was mentioned in several penal proceedings.

In 11 of the cases, the defendants were sentenced exclusively for purchase or possession of illegal drugs "on a large scale", but "without the purpose of sale" (Art. 228, par. 1) (see Table 3). In a much larger number of cases, however, the defendants were sentenced for the offence of "acquisition or keeping of illegal drugs for the purposes of sale", which is defined in the second paragraph of Art. 228. However, the second paragraph itself was not resorted to in any of the criminal cases analyzed. In 14 cases, reference was made to the aggravating circumstances foreseen by the third paragraph of Article 228, which states:

The acts provided for by paragraph two of the present Article committed:

(a) by a group of persons by prior collusion;

(b) repeatedly;

(c) with respect to narcotic means or psychotropic substances on a large scale -

shall be punished by deprivation of freedom for a term from five up to ten years with or without confiscation of property (Butler, 1997, p. 134).

In almost half of the cases analyzed (23), the fourth paragraph of Art. 228 was employed: 


\section{Drug Trafficking in Russia}

The acts provided by paragraphs two and three of the present Article committed by an organized group with respect to narcotics means or psychotropic substances on an especially large scale -

shall be punished by deprivation of freedom for a term from seven up to fifteen years with confiscation of property (Butler, 1997, p. 134).

The application of the latter provision was particularly frequent in St. Petersburg's cases (18), whereas Omsk courts resorted much more frequently to the third paragraph of Article 228. Finally, in three cases of the Krasnodar courts, Article 231 was applied, which entails the offence of "illegal cultivation of flora containing narcotic substances prohibited for tilling” (Butler, 1997, pp. 136-137).

Even if we focus on only the 40 cases in which drug dealing or drug production were foreseen (Art 228, par. 3 and 4, and Art. 231), we cannot find proof of any large criminal group. In some cases there are "crews", partnerships of three or four people who buy and sell illegal drugs. The sentence issued on May 12, 1999 by the Kuibyshevsky Federal Court of St. Petersburg's Central District, for example, involves four women, three of whom worked together for more than half a year as drug dealers. The trio bought 40-gram lots of marijuana from unidentified persons at least nine times, and in January 1998 repeatedly bought a kilo of marijuana and sold the drug in smaller portions to several customers, including the fourth defendant (Kuibyshevsky Federal Court, 1999a).

TABLE 3

Selected Criminal Cases, According to the Article of the Russian Criminal Code Applied*

\begin{tabular}{lcccc}
\hline & $\begin{array}{c}\text { Art. 228, } \\
\text { 1st par. } \\
\text { only }\end{array}$ & $\begin{array}{c}\text { Art. 228, } \\
\text { 3rd par. }\end{array}$ & $\begin{array}{c}\text { Art. 228, } \\
\text { 4th par. }\end{array}$ & Art. 231 \\
\hline St. Petersburg & 4 & 3 & 18 & - \\
Krasnodar & 5 & 3 & - & 3 \\
Omsk & - & 6 & 3 & - \\
Nizhniy Novgorod & 2 & 1 & 3 & - \\
Moscow & - & - & 1 & - \\
Total & 11 & 13 & 25 & 3 \\
\hline
\end{tabular}

* The first column includes only the cases in which the defendants were exclusively accused of the offence defined by the first paragraph of Art. 228. The second and third columns include cases in which the most serious offence was respectively represented by the third or the fourth paragraph of Art. 228. In nine of the cases listed in the second column and ten of those listed in the third one, however, less serious offences (most frequently, the first paragraph of Art. 228) are also mentioned. 
Aramais A. and Ararat A., two Armenian nationals, were sentenced in Omsk, respectively, to nine and four years imprisonment, for repeatedly buying and selling heroin from and to unidentified persons. Though they were only two persons, in this case the fourth paragraph of Art. 228 was applied, which foresees the involvement an "organized group", because 34 grams of heroin were seized (Sovietsky District Court of Omsk, 1999).

Another sentence issued by an Omsk court was directed against five defendants, who were convicted according to Art. 228, par. 3, alternatives (a), (b), (c). After buying at least 339.4 grams of opium from an unknown person, Andrej G. recruited the couple Andrej V. and Julia L. for the drug's retail sale and left most of the opium at their place of residence ( 300 grams were subsequently seized there by the police). Unwilling to sell opium herself, Julia L. packed it in smaller bags and passed it on to Olga, who probably sold some of it and was arrested with 0.9 grams of opium (Leninsky District Court of Omsk, 1999).

In many cases, furthermore, even when the third or the fourth paragraph of Article 228 was applied, no group existed strictu sensu at all. As the staff of the Research Institute of the Prosecutor General's Office put it,

the groups described in the cases do not meet the conventional criteria of a group nor present the well organized character of the criminal activity related to illegal drug trafficking. In most cases, a drug transaction between the buyer and the seller or even the common purchase of illegal drugs by two users are considered sufficient to prove the existence of a group (RIPGO, 2000, p. 52).

Furthermore, according to the Russian jurisprudence, this assumption holds even when the other components of the group remain unknown. This is often the case as most cases, even those resorting to the third and fourth paragraph of Article 228, entail only one defendant. Out of the 52 that were analyzed, in fact, in only 16 cases was there more than one defendant: two persons stood together on trial in 12 proceedings; three persons in two, and four and five persons in one penal proceeding each (see Table 5).

Galina G., for example, was sentenced by the Petrograd District Court of St. Petersburg (1999b) on August 19, 1999 to three years imprisonment according to Art. 228, par. 4, for having bought 0.082 grams of heroin, transporting it home and selling it to a second person. The 25-year-old Ruslan P. was sentenced by the Kuibyshevsky Federal Court of St. Petersburg's Central District in October of the same year and according to the same penal provision, for the purchase of less than half a gram of heroin ( 0.451 grams $)$ from an unidentified person. On at least two occasions he sold two doses ( 0.022 and 0.015 grams each) to I. and on the basis of these transactions, Ruslan P. was thought to be belong to "an organized criminal group" as foreseen by Art. 228, par. 4 (Kuibyshevsky Federal Court, 1999b). 
TABLE 4

Selected Criminal Cases, According to the Number of Defendants

\begin{tabular}{lr}
\hline 1 defendant & 36 \\
2 defendants & 12 \\
3 defendants & 2 \\
4 defendants & 1 \\
5 defendants & 1 \\
Total & 52 \\
\hline
\end{tabular}

In some cases, relatively large quantities of illegal drugs were involved. Alexander T. was convicted in October 1999 by a St. Petersburg court for having bought at least 993 grams of marijuana and selling the drug in smaller portions to several customers (Petrograd District Court 1999d). Likewise, in Nizhniy Novgorod two Tajik nationals were sentenced ex Art. 228, par. 4, for smuggling at least 144 grams of heroin from their home country (Moscovsky District Court, 1999).

In some other penal proceedings, however, the third and fourth paragraphs of Article 228 were applied, though the quantities of the retrieved drugs were very small (by Western standards at least) and the accomplices of the defendant remain unknown. Eleonora K. was sentenced to five years imprisonment pursuant to Art. 228, par. 1 and 3, for purchasing ephedrine and manufacturing $3.3 \mathrm{ml}$ of vint, though no purposes of sale could be proved (Leninsky District Court of Krasnodar, 1997). The amount was considered "large scale" by the court, which hence applied alternative (c) of Art. 228, par. 3. The same considerations led to a 5-year prison sentence for Olesia S., who sold 0.15 and 0.17 grams of opium, after buying it from an unidentified person (Sovietsky District Court, 1999b). The Petrograd District Court of St. Petersburg even applied the fourth paragraph of Art. 228 against the 28-year-old Jury T., who had bought 0.091 grams of heroin and partially sold it to a second person $\mathrm{P}$. The latter transaction was allegedly deemed sufficient for fulfilling the criteria set by the above provision, which should refer to crimes "committed by an organized group with respect to narcotics means or psychotropic substances on an especially large scale" (Petrograd District Court, 1999a). The same provision was also resorted to in the case against Denis T. and Maxim G., who had bought 0.0058 grams of heroin together and subsequently sold it in readyto-use syringes (Petrograd District Court, 1999c).

Despite the growing complexity of the Russian drug market, the criminal cases show that, especially out of Moscow and St. Petersburg some drug users still harvest or cultivate plants containing psychoactive substances, most notably cannabis and 
poppy. Three of the 52 cases reviewed, in fact, involved the cultivation of cannabis plants $(28,166$, and eight respectively) by the three defendants on their own pieces of land (Leninsky District Court of Krasnodar, 1999; Sovietsky District Court of Krasnodar, 1998, 1999a). In three other cases, all processed by courts in Nizhniy Novgorod, the defendants were convicted for collecting wild poppy and extracting poppy milk (Nizhniy Novgorod District Court, 1998; Kniagininsky District Court, 1999; Tonshaevsky District Court, 1999).

Most of the defendants were relatively young. The overall majority was not yet 30 years old when the investigation started. Out of 78, in fact, 54 defendants were born in or after 1967. Eighteen of them were not older than 22 years old when they were sentenced. Older and supposedly more experienced dealers are less frequently present in our sample.

At least half of the convicted persons are drug users themselves. In many other cases, however, the courts made no effort to prove whether the defendants used illegal drugs (RIPGO, 2000, p. 51). According to the RIPGO, this is not the only shortcoming of the cases examined. In its own report, in fact, the Research Institute of the Prosecutor General's Office states:

the analysis of penal proceedings shows the poor quality of the investigations conducted in all examined cases. As a rule, the proof of the drug sale consists in two, maximally three episodes of elementary drug exchanges with a friend or a known person. In none of the examined cases could the supplier of the drug seller be found....Though it was obviously very simple to prove the guilt of the defendants, in $19.3 \%$ of the examined cases the courts admitted to an infringement of procedural norms concerning law enforcement investigations (RIPGO, 2000, p. 51).

\section{The "INVISIBLe HAND" of the MaRket}

The relatively "disorganized" nature of drug trafficking and distribution in Russia is further proved by the fieldwork in several Russian cities. In all of them a multilevel drug distribution system has developed and today users increasingly buy their drugs from the dealers, instead of cultivating or harvesting themselves. The latter's demands, however, seem to be neither satisfied nor promoted by large, hierarchically-organized firms that monopolize local markets. It is understandable that professional and non-professional observers hypothesize the involvement of a powerful "Russian mafia" to explain the sudden expansion of illegal drug consumption and trade in Russia. Nonetheless, the fieldwork as well as interviews with several experts provide no backing for such a hypothesis. The phenomenal growth of drug use can rather be attributed to the "invisible hand' of the market: the local drug markets of Russian cities are today largely supplied by a myriad of drug dealers who tend to operate alone or in small groups and often consume illegal 


\section{Drug Trafficking in Russia}

drugs themselves. In many cases the latter do not even possess any previous criminal expertise and deal with illegal drugs to make a living or to supplement the meager income they obtain from licit activities. As a Moscow police officer put it,

there are no Colombian drug cartels here. There are instead many small groups that are made of people belonging to the same nationality or ethnic group. There is not one single river, but many streams that flow independently on one another (Interview A6).

In all the nine cities where the fieldwork was conducted, the lowest and most dangerous levels of the local distribution systems are increasingly occupied by drug users themselves. In order to pay their own consumption habits, the latter are obliged to sell small quantities of drugs, work as intermediaries and, more rarely, to transport drugs (Gilinsky, Kostjukovsky, \& Rusakova, 2000, p. 23; Markoryan, 2000). As a drug user interviewed in St. Petersburg put it, "if I sold less then one gram of heroin per day, I had no money for my doses. I was always obliged to sell drugs to buy my dose. Sometimes I had no success for two or three days and I hence borrowed money. As a result my debt grew..." (Gilinsky, Kostjukovsky, \& Rusakova, 2000, p. 29). Likewise, another user interviewed in Moscow admitted, "drug addicts often are themselves dealers, due to the business' high profits: if you deal, you can leave purer heroin for your own consumption and cut and sell the rest" (Interview H14).

The higher levels of the local drug distribution systems are often occupied by dealers and user-dealers belonging to ethnic minorities, most notably members of the Roma community, Caucasians as well as Tajik and Afghan nationals (see Dragan \& Kalachev, 1997).

Having tenaciously resisted integration in Soviet society, a considerable fraction of the over 150,000 gypsies who were officially resident in the Russian Federation in 1987 (Crowe, 1994, p. 193) turned to illegal or semi-legal activities to make a living after the collapse of the Soviet Union. In particular, many of them got involved in retail drug dealing and now sell drugs on the periphery of most Russian cities and towns. In Moscow, as well as in Rostov, in Krasnoyarsk as well as in Khabarovsk or Vladivostok, the Roma villages that are located at the city's outskirts are the best place to buy drugs, local drug users report (Interviews H13, D6, and A1; Saukhat, 2000; Maiorova, 2000; Rakitsky, 2000; Zavadskaya, 2000). According to a study of the Research Institute of the Russian Ministry of the Interior, Roma women are more involved than men in the drug trade, which often constitutes an important source of the family income. Gypsies, however, are largely active at the retail level of the drug market and, despite the existence of Roma communities in most Russian regions, they seem to be scarcely involved in the interregional wholesale trade (Research Institute of the Ministry of the Interior [RIMVD], 2000; Interviews H13 and A6; contra FSB, 2000, passim). 
Especially in the European parts of Russia, Caucasian nationals are also active in street dealing. In several cities, the latter were described by many drug users as the typical dealers. As one of them, interviewed in St. Petersburg, put it,

The typical drug dealers are zverki (persons of Caucasian nationality) and gypsies. There are family clans that have been sold drugs for a long time. They are preferred by users, because in general our Russian sellers are either drug addicts themselves or undercover policemen...or they do not sell drugs in good places (Gilinsky et al., 2000, p. 25).

In many cities of the European Russia, Caucasians and, above all, Azeris work in and often run the open-air markets for food and clothes. When the perestrojka reforms allowed private trade, the migrants from the Caucasus areas were the first to exploit this chance and began to trade in vegetables, meat and clothes. Many of these new traders had moved to Moscow, St. Petersburg or other large European Russian cities in the late 1970s and early 1980s to work as contract workers in the building industry and in other sectors of the economy. Unlike those who migrated after the Second World War, limitschiki, as contract workers are nicknamed in Russia, had serious difficulties to integrate in Soviet and then, Russian society. Lacking better alternatives, many of those who remained after the contract expired, and the few who had migrated independently in the late 1980s, exploited the chances opened by Gorbachev's reforms and became street traders (Snisarenko, 1997, pp. 142-144).

Especially in the case of Azeri migrants, their presence in Russia rapidly increased after the collapse of the Soviet Union, when thousands of people migrated from the war-torn areas in Nagorno-Karabakh and at the Armenian border (see Hunter, 1997; Halbach, 1999; Goldenberg, 1994). According to some estimates, there are now two million ethnic Azeris living in Russia (Kurbanov, 1999). Most of the new migrants, however, did not register themselves as residents, because in most cases they would have been refused a residence permit, nor claimed a refugee status, though they were entitled to it. The Russian migration offices, in fact, usually do not allow refugees to live in large cities, but send them in other regions or in smaller cities and villages of the surrounding regions (Snisarenko, 1997).

Having no resident and work permit, most of the new migrants have no access to the legal economy and, in order to survive, have no choice but to work in the city's underground economy. Most of them end up finding jobs in the open-air markets. As a result, since the mid-1990s most traders have had an irregular status and the markets have become a lawless space, where the order is guaranteed by the chiefs of the most powerful clans. Due to their secrecy, the authority structure of Azeri or Caucasian markets has not been properly studied yet. It is clear, however, that this structure is at least potentially an alternative to state power, which is largely unable to control and to regulate the market (Snisarenko, 1997). 


\section{Drug Trafficking in Russia}

In such a context, illegal drugs can easily become an attractive commodity for the most entrepreneurial and/or the most needy migrants working in open-air markets. For those who are used to living and working in irregular conditions, selling illegal drugs does not probably look much different than selling, say, potatoes or onions. Furthermore, the informal rules and procedures that were created to regulate the import and trade of legal goods can be applied without problems even to illicit drugs. Finally, there are practical advantages: market traders are used to importing commodities from abroad or other distant Russian regions and often can use the shipments of their usual legal goods to smuggle illegal drugs.

Caucasian drug dealers are often described as belonging to large criminal organizations, which are mafia-like (Dunn, 1997; FSB, 2000, passim). According to two police officers interviewed in Moscow and to information drawn in other Russian cities, however, Caucasian drug dealing groups seem rather to be composed of a limited number of people and to be based on family, clan or locality ties (Interviews A1 and A6). Indeed, though migrants from the Caucasus are often lumped all together, they belong to a variety of ethnic groups and solidarity relationships, which are most useful for the accomplishment of illegal activities and are usually founded on very localized principles, such as the membership in the same family, clan, or village (Snisarenko, 1997).

Despite the advantages deriving from the reliance on family or locality ties, Caucasian dealers increasingly feel the competition of Afghan and Tajik sellers, who have an incomparable strength. The latter two originate from the No. 1 world heroin producer country and from heroin's first, almost unavoidable, transshipment point respectively. Several drug users, interviewed in Moscow and St. Petersburg, point out that their dealers are Afghan and, above all, Tajik nationals. The latter, coming from a former Soviet republic, have no problems entering the country, usually speak Russian, and have either many contacts or even a residence permit in Russia. As the 19-year-old Anthone notes, "in Moscow there are a lot of Tajik dealers by now" (Interview H7; see also Interviews H9, H12, D6, A1, and A6). Throughout Russia local MPI research teams reported the involvement of Tajik nationals in the heroin trade and street distribution (Maiorova, 2000; Markoryan, 2000; Rakitsky, 2000; Gilinsky et al., 2000: 25-26; Obidina, 2000; Zavadskaya, 2000).

According to many interviewees, many Tajik dealers are themselves drug consumers and do not belong to a large-scale criminal organization, but often bring themselves heroin from Tajikistan to make ends meet. As the 25-year-old heroin user Alesia states, "many Tajik dealers use drugs themselves" (Interview H8). Likewise, a drug user in St. Petersburg maintains:

I usually buy drugs in the open-air market. The typical seller there is Tajik or, anyhow, "black". As a rule, he is very fussy, sometimes on drugs. They 
buy heroin in Tajikistan (about $\$ 3$ per gram) and bring it to Russia in condoms, distribute it among street dealers in small portions and sell it at a much higher price (Gilinsky et al., 2000, p. 25; see also Interviews H7, H8, H9, H12).

According to Russian customs' sources, many Tajik traders are blackmailed by drug trafficking organizations and obliged to smuggle heroin into Russia. Relying on the statement of several detained couriers, in its latest drug report the State Customs Committee described the following recruitment scheme. An aspiring Tajik trader is granted a loan to buy some goods (most usually, vegetables and fruits) for sale in Russia. Before the shipment, the cargo is stolen or destroyed, as if by accident. The trader falls in financial difficulties and he is offered the chance to smuggle heroin to repay his debt. His family and relatives are often held as hostages and his house and assets as a kind of mortgage. If the trader refuses or he is detained by law enforcement authorities, the mortgaged properties are sold or destroyed (SCC, 2000, p. 18).

It is impossible to say how often this recruitment scheme is employed. Given the dire economic conditions and the widespread availability of heroin in Tajikistan, however, it is probably not necessary to resort to it very often, as there must be plenty of volunteers (Interviews B7 and F3). As a Russian law enforcement officer put it, "people have to live somehow and often have no choice but to deal drugs" (Interview A7). The huge expected profits of heroin smuggling are also a powerful lure for impoverished Tajik and Afghan citizens. In fact, a gram of heroin costs as little as US\$ 3 (86 rubles) in Tajikistan and even less in Afghanistan (US\$ 1-1.5; see OGD, 2000: 41). In Moscow or any large Russian city, the same amount can be sold for at least 400 rubles (US\$ 10.50) at the wholesale level, or for 1,000 rubles (US\$ 35) at the retail one. A kilogram of heroin can be bought for US\$ 2,000 in Tajikistan and sold for US\$20,000 or slightly less in any major Russian city (Interviews A6, A3, A6 and B2). The real mark-up, however, is not merely tenfold, as these figures would imply, but much higher because heroin can be cut several times before it reaches the final consumer.

According to Moscow's police officers, groups of heroin smugglers from Afghanistan and Tajikistan are usually composed of five to ten people, which may on exception expand up to 20-25. Only when the whole smuggling network from Tajikistan to Moscow is taken into account, may the number of people involved reach 50. The strength and cohesion of these (and other) illegal networks, however, should not be overestimated. Although long-term relations may develop among network members, the majority of them are arm's-length buyer-seller relationships, which are neither exclusive in any sense nor centrally organized. Each drug dealer is usually free to look for other partners to execute the next transaction and often belongs to more than one network at the same time, since he has contact with several suppliers and has numerous customers to whom he can sell his merchandise. 


\section{Drug Trafficking in Russia}

Moreover, in any position of the network, the actors generally know only their immediate supplier(s) and buyer(s) and have no idea of the network's overall extent and structure. Finally, it must never be forgotten that illegal networks are volatile constructions. They constantly change their form and extension, as partners are included, are occasionally or permanently discarded, or are replaced because they have been targeted by law enforcement action (Paoli, 1999a and 1999b; see also Interviews A1 and A6).

The activity of Tajik dealers is prototypically described in a case that was provided by Moscow militia officers and was issued in December 1998 by a District Court of Moscow (1998). Four Tajik nationals, three men and a woman, were the defendants in this case and they were all found guilty of membership in a "criminal society" to smuggle large quantities of heroin from their home country. Šerali K. and Armonso M. (born in 1968 and 1969 respectively) were the leaders of the group, which was also composed of the younger Farkhod D. (born in 1976) and Dilorom $\mathrm{H}$. The latter is a woman in her thirties with three small children, who used to teach at the Tajik State National University and who had no previous police record. Undercover agents of the Moscow police had contacts with Farkhod and organized several controlled purchases for amounts ranging from one to 500 grams of heroin. In the case, the Moscow district court stresses the efficiency and organization of the group, which is regarded as a veritable "criminal society". In fact, it writes:

In the course of the investigation it was proved that all four defendants joined their forces for the common purposes of expanding the illicit business of drug dealing on a large scale. The criminal society is characterized by its steadiness, hierarchic structure (leaders, subordinates who perform the tasks, the exact distribution of functions and duties), strictly elaborated scheme of drug trafficking operations. For example, the addresses of the drug deposits are never revealed; drugs and money are exchanged only through several intermediaries. The buyer never knows in advance the place where the transaction will take place, a first meeting is made in a place and, when the buyer arrives there, he is told to go somewhere else. The criminal group was ready to traffic unlimited big amounts of drugs, as long as there was a demand for them, and was ready to deliver them in a short-term. Furthermore, the criminal group was well informed about the source of the drug smuggling to Moscow, and about the place where the drugs were stored (District Court of Moscow, 1998).

Though the group is classified as a "criminal society", none of the information provided by the court seems sufficient to prove the existence of a structured and stable organization from a sociological point of view. According to the latter standards, the group under examination can be rather considered a short-term 
partnership. Composed of four people, it operated for less than a year, before being dismantled by the law enforcement operation. Though there was certainly an elementary division of labor and an internal hierarchy, the group de quo was far from being comparable to any large-scale legal corporation. Furthermore, many of the precautions listed by the court are usual for every person or group selling illegal commodities (Reuter, 1983; 1985; Reuter \& Haaga, 1989; Moore, 1974; Paoli, 2000a). The label "criminal society" lets many Western observers think about powerful criminal associations resembling the mythical image of the ItalianAmerican Mafia, as it has been described in many popular books and movies (e.g. Puzo's The Godfather) (Bäckmann, 1998; Rosner, 1995). Beyond the label, however, the reality seems to be much different not only in the USA, but also in Russia.

As relatively small amounts of heroin are each time imported from Tajikistan, the drug distribution chain is usually rather small and does not entail more than three or four levels, including the final consumer. The importer is at the same time the wholesale dealer, who sells heroin in smaller lots, when he arrives in a Russian city. The latter's customer sometimes sells directly heroin to the users but most often he supplies a retail dealer, who distributes on the street (Interviews H1, H12, and H13; see also Saukhat, 2000; Markoryan, 2000).

According to Moscow's police officers, many, though not all, Tajik dealing groups have to pay a "protection tax" to more established criminal associations that claim sovereignty on specific Moscow quarters. In some cases, up to 25-30\% of the drug profits need to be passed on by the dealers to these extortionist gangs (Interviews A6 and A5). However, the large groups as such have so far remained largely uninvolved in the drug business, though some of their younger affiliates may deal drugs (Paoli, 2001a).

Up to the mid-1990s even the Chechens were said to be heavily involved in drug trafficking and distribution (RIMVD, 2000) and, indeed, their groups and clans were often presented as the prototype of the Russian organized crime (Dunn, 1997; Ministero dell'Interno, 1993). Chechens' presence in Russia, however, rapidly sank during and after the first war in Chechnya (1994-1996), when many of them went back: according to Russian law enforcement forces, to fight in the separatist guerrillas, according to Chechen organizations and international NGOs, to escape growing racism and discrimination in Russia. Following the start of the second Chechnya war, many came back as refugees, though they have not been officially granted such a status. According to some estimates, between 50,000 and 100,000 Chechens currently live in Moscow alone (Hille, 2000; Halbach, 1999, pp. 12-14). Whereas in the early 1990s Chechen gangs were said to terrorize the city (Handelmann, 1995), most Chechens now maintain a low profile, to avoid falling in the law enforcement net. Unidentified Chechen persons have been, in fact, suspected of organizing the series of bomb explosions that has hit Russia, and, 


\section{Drug Trafficking in Russia}

most importantly, Moscow since the summer 1999. Numerous Chechens report being arbitrarily arrested, detained and even tortured by the police in the aftermath of each terrorist attack (Hille, 2000; Amnesty International, 1999).

According to the local law enforcement forces, Chechens and Ingushes still play a central role in the supply and distribution of illegal drugs in the neighboring North Ossetia (MVD-North Ossetia, 2000; Ciklauri, 2000). Chechens' involvement in drug trafficking was also reported by the FSB in some European cities, such as Kirov, in the Saratov region in Southern Russia, in the Kurgan region in the Urals, the Tyumen and Tomsk areas in Western Siberia, and the Tyva Republic in Eastern Siberia (FSB, 2000, passim; see also BBC, 2000).

According to both the FSB and the Research Institute of the Ministry of the Interior, members of other ethnic minorities, above all Georgians, Dagestanis, and Armenians, but also Uzbeks, Kazakhs, Kyrgyzs and, to a lesser extent, Chinese supply illegal drugs to local markets of numerous Russian cities (FSB, 2000; RIMVD, 2000). In Moscow and St. Petersburg, black Africans are also said to be involved in drug smuggling and dealing and, according to several observers, the latter were the first to import heroin in Russia. Many of these are registered as students and in Russia's capital, live and work above all around the Lumumba University (Interview B2 and D6).

Though the members of some ethnic communities may be over-proportionally represented in the drug distribution system of many Russian cities, they are far from occupying it all. Indeed, the central role Caucasians and Tajiks end up assuming in the official and popular accounts of Russian thriving illegal drug markets is also due to their visibility - the former usually sell drugs in open markets - and to the growing ethnic prejudices of large sectors of the Russian population towards "Caucasian nationals" and, more generally, southerners (see Kurbanov, 1999; Snisarenko, 1997; Brednikova, Cikadze, \& Snisarenko, 1997; Human Rights Watch, 1995). This stigmatization process is most evidently carried out in the Christian Orthodox Republic of North Ossetia vis-à-vis the neighboring Muslim people of Ingushetia and Chechenya. Above all in the local media, but also in the reports and official statements of the local government authorities, the latter are constantly presented as the archetypal dealers. Furthermore, they are accused of employing drugs to weaken the North Ossetian people and corrupt their genetic make-up. On December 10, 1999, the Severnaja Ossetia, the most widely read local newspaper, wrote:

The spread of narcotics in our republic goes beyond drug traffickers' financial interests and assumes the character of a clearly-planned, long-term action. The specialists of the Drug Control Department of the North Ossetian Ministry of the Interior are currently analyzing shocking information: our republic has been recently supplied from certain regions with heroin, that was cut 
with the blood of AIDS-infected people. According to the investigators, there are grounds to talk about a specific attack against the genetic make-up of the North Ossetian nation. If such a preparation were to be diffused, the consequences could be incalculable (Cikluari, 2000, p. 30).

The rivalry with the Ingush and Chechen neighbors is so well rooted that there is no need to specify which "the certain regions" are (Cikluari, 2000, p. 30).

Contrary to many stereotyped expectations, the members of ethnic minorities are not alone in their involvement in the drug trade. In contemporary Russia illegal drugs are produced and sold also by many people who cannot be easily classified in a precise scheme, because they belong to the mainstream Russian population. As Ludmila Markoryan from Balakovo (a Southern city of 200,000 inhabitants on the Volga) points out,

it is not easy to refer the drug dealers of our city to specific social groups. Dealer might be a housewife, a jobless person, or a businessman. The age range of middle and high-ranking drug dealers also varies tremendously: there are young people as well as retirees. In the last few years we noted a tendency to engage adolescents aged 10-14 in drug use and dealing, since they cannot be legally prosecuted (Markoryan, 2000).

This point was also recognized by some drug users, interviewed in Moscow and St. Petersburg. According to the 19-year-old Anthone, for example, "the production, transportation, and sale of illegal drugs are carried out by all social and national groups" (Interview H7).

Throughout the 1990s retail drug dealing has become a last resort to make ends meet for those who have been most hit by Russia's economic and social transformations. As the 21-year-old Vika points out, "next to pharmacies, in subway stations, many old women sell drugs" (Interview H11). Unable to live on their meager state pensions, scores of otherwise respectable old people have entered into the drug business in Moscow and other Russian cities. Elderly pushers usually sell medicines they obtain on prescription, above all, the cough syrup Solutan ${ }^{\circledR}$, which drug users process to obtain vint. In the late 1990s, up to 50 elderly dealers were brought into the Kitaj Gorod police station near the Lubjanka square every day. Though some of them were sentenced for drug trafficking, most of these pensioners were searched, held for a few hours and usually released after paying a fine (Franchetti, 1998).

Even in other Russian regions, drug production and trafficking have become a viable alternative to make ends meet for a significant part of the population. In the Far East as well as in the South many farmers are increasingly involved in the cultivation, harvest and distribution of cannabis, in order to survive (see Rakitsky, 2000; Saukhat, 2000; Morvant, 1996). In the Caucasian Republic of North Ossetia, 


\section{Drug Trafficking in Russia}

women account for $90 \%$ of the people arrested for drug dealing in the late 1990 s. According to Eliko Ciklauri,

the typical profile of these women is as follows: aged 30-40, jobless, divorced or single mothers of two or three small children. Already this typical profile lets us suppose that they are not "professional dealers" but have been obliged by their living conditions to sell drugs (2000, p. 23).

To understand why this happened, it is probably helpful to recall a few data on the effects of the transition to the market economy in the 1990s. According to the data provided by the State Statistics Board, real money incomes decreased by almost $50 \%$ since 1990. The August 1998 crisis caused a drop in the real money incomes of the population below the 1992 level. Not only was the average per capita monthly income estimated at a mere 1,469 rubles (US \$51.40) in July 1999, but also almost half of the workforce did not receive regular pay during the second half of the 1990s. In July 1998 it was calculated that at least 8 to 10\% of Russian employees had not been paid wages for more than six months. In July 1999 the average monthly pension in Russia amounted to only 418 rubles (US\$ 14.60), or 30\% of the average wage. As of July 1999, there were 51.7 million people who lived below the subsistence level, representing $35.3 \%$ of the whole population (United Nations Development Program [UNDP], 1999, pp. 42-46; Tchernina, 1998).

Furthermore, in addition to the drop in average per capita incomes during the 1990s, there has been a drastic increase in inequality of incomes and wages. Though different estimates have been produced, most scholars maintain that inequality in Russia today is commensurable to the Latin American level. According to one study, the incomes of the top $10 \%$ wealthiest exceeded the incomes of the $10 \%$ least wealthy by 65 times (UNDP, 1999, p. 65).

Inequality and the contemporary appearance of a wide range of goods and services, which were unknown and unavailable to most Soviet citizens, further exacerbate the perception of one's own poverty. As R.V. Ryvkina noted:

Poverty is not only a material status, but also a state of mind. The differentiation between people and the social distance between the rich and the poor, which has dramatically worsened during liberalization of the economy, are aggravating the sense among people of their own poverty. And since, not only rich, but also super-rich people have appeared in Russia for the first time, and not only appeared but also changed the nature of many spheres of services ... this increases the feeling of poverty among the bulk of the population (Ryvkina, 1998, pp. 18-19).

To avoid starvation or to afford a small luxury, most people are obliged to look for a secondary income, in addition to their first official one. According to Russia's tax authorities, around 20 million people, i.e. more than a quarter of the country's 
economically active population, have a non-reported part-time job. Most people obtain only 30 to $35 \%$ of their income from their so-called main place of work. The remaining $75 \%$ is achieved on the side from second and third jobs, which no statistics take into account and which are not subject to any taxation. Between $25 \%$ (the State Statistics Board's estimate) to $50 \%$ (the Interior Ministry's estimate) of the total Russian GDP is created in the shadow sector (UNDP, 1999, p. 45; see also Dolgopjatova, Simacev, Tambovcev, and Jakovlev, 1999; Glinkina, 1999).

As most people are used to participate (at least as a buyer) in the country's booming underground economy, for the most destitute or entrepreneurial ones it may seem a short step to start dealing illegal drugs. The moral restraints are furthered lowered by the realization that many of the rich and super-rich "New Russians" have accumulated their fortunes by illegal or semi-legal means. As a result, Ludmila Markoryan notes, "there are whole families whose main income is earned through drug dealing" (2000).

\section{The Drug Trade and Organized Crime}

In the academic and international political debate, there is no unanimous definition of organized crime. Indeed the latter is an ambiguous, conflated concept, produced by a stratification of different meanings, which have been attributed to the term "organized crime" since the end of the Second World War (Paoli, 2001b). Depending on the definition we select, the Russian drug trade or its participants can be regarded organized crime or not.

In the American and Northern European scholarly debate, organized crime is often equated with the provision of illegal goods and services: hence, for example, according to Block and Chambliss, "organized crime [should] be defined as (or perhaps better limited to) those illegal activities involving the management and coordination of racketeering and vice" (1981, p. 13). Organized crime is thus considered a synonym of illegal enterprise. Indeed, according to a review of definitions carried out by Frank Hagan in the early 1980s, a consensus now exists among American criminologists that organised crime involves a continuing enterprise operating in a rational fashion and focused toward obtaining profits through illegal activities (Hagan, 1983).

If this definition is accepted, it is obvious that illegal drug production and trafficking, in Russia as anywhere else, represents a form of organized crime. In the scientific, but above all in the political debate, however, organized crime is not usually understood as a set of illegal activities, but it is instead identified with a set of large-scale organizations that either illegal in se or are predominantly involved in contra legem activities. This second conception is well illustrated by the following definition: "organized crime consists of organizations that have durability, hierarchy and involvement in a multiplicity of criminal activities....The Mafia provides the most enduring and significant form of organized crime" (Reuter, 1985, p. 175). 


\section{Drug Trafficking in Russia}

If this second definition is accepted, the answer to the above question needs to be changed. In fact, we have yet no grounds to affirm that drug production and trafficking in Russia are run by organizations fulfilling the criteria set by Peter Reuter's definition. Though there are contrasting opinions on this matter (MVD, 2000; FSB, 2000), this conclusion is backed by the analysis of criminal cases and the fieldwork in several Russian cities. It is also confirmed by the statements of some Russian and most foreign law enforcement officials who were interviewed during the present research. As one of the latter put it,

I hardly dare to tell it my colleagues back home, but for the moment we have no proof of a large-scale involvement of Russian organized crime in the illegal drug trade. Our investigations so far show that the latter is characterized by a low level of sophistication and organization (Interview B1; see also Interview B7).

A "disorganized" view of the supply side of the Russian drug market was also offered by the head of the North Ossetian FSB in a 1998 parliamentary hearing in Vladikavkaz. On the basis of the preceding analysis his conclusions can also be extended to other Russian regions:

The available information does not support the hypothesis that a narco-mafia exists on the territory of our republic. Narcotics are usually smuggled by single persons or group of people, that are not linked to one another (FSBNorth Ossetia, 1998; Ciklauri, 2000, p. 28).

This representation of the illegal drug trade in Russia mirrors the functioning of illegal drug markets in Western Europe and the USA. In a recent project sponsored by the European Monitoring Centre for Drugs and Drug Addiction (EMCDDA), for example, Paoli found out that in two major Western European cities, Frankfurt in Central Germany and Milan in Northern Italy, the great majority of drug deals, even those involving large quantities of drugs, are carried out by numerous, relatively small, and often ephemeral enterprises. Some of them are family businesses: that is, they are run by the members of a blood family, who resort on an ad hoc basis to a net of non-relatives in order to carry out the most dangerous tasks. Some are veritable non-kin groups, which are formed around a (charismatic) leader and then manage to acquire a certain degree of stability and develop a rudimentary division of labor. Others are "crews": loose associations of people, which form, split, and come together again as opportunity arises. Indeed, especially at the intermediate and lower levels, many dealers work alone, either to finance their own drug consumption habits or, more rarely, to earn fast money. Most of these drug entrepreneurs have no contact whatsoever with the underworld, but are often inconspicuous persons, who can hardly be distinguished from "normal" people (Paoli, 2000a; see also Reuter \& Haaga, 1989; Adler, 1993). 
Even Southern Italian mafia families, whose members were deeply involved in large drug deals in Milan during the 1980s and early 1990s, do not seem to operate as monolithic productive and commercial units. On the contrary, their members frequently set up short-term partnerships with a few other mafia affiliates or even with external people to make drug deals. These "crews" are far from being stable working units that could be compared to the branch office of a legal firm. Their composition frequently changes depending on the moment when deals take place or on the availability of single members. After one or a few drug transactions some teams are disbanded, while others continue to operate for a longer time, eventually changing their composition to some extent (see also Paoli, 2000b, 2000c).

More generally, it is worth stressing that in all Western countries, but to a lesser extent also in Russia, drug entrepreneurs of all kinds are subject to the constraints deriving from the illegal status of the products they sell. These constraints have to do with the fact that all illegal market actors - are particularly drug traffickers and dealers - are obliged to operate 1) without and 2) against the state.

1) Since the goods and services they provide are prohibited, illegal market suppliers cannot resort to state institutions to enforce contracts and have the violations of contracts prosecuted, nor does the illegal arena host an alternative sovereign power to which a party may appeal for redress of injury (Reuter, 1983, 1985). As a result, property rights are poorly protected, employment contracts can hardly be formalized, and the development of large, formally organized, enduring companies is strongly discouraged.

2) All suppliers of illegal commodities - and specifically drugs - are bound to operate under the constant threat of being arrested and having their assets confiscated by law enforcement institutions. In reality, the effective risk of arrest and interception of assets varies according to the situation and the counterparts involved. Some illegal entrepreneurs are so successful in bribing representatives of state institutions and/or the latter are so weak and inefficient that the risk is in effect strongly reduced. In most Western countries, however, the risk of arrest and interception of assets can hardly be disregarded in the long run. In varying degrees, all illegal market actors risk imprisonment and the seizure of their properties by law enforcement agencies and must take precautions against such events.

Due to the low pay, poor equipment and corruption of Russia law enforcement forces, this risk may be currently lower in Russia than in most Western countries (see Paoli, 2001a). Nonetheless, it cannot be completely neglected even by illegal drug entrepreneurs operating in Russia. Each participant in the drug trade will thus try to organize his activities in such a way as to assure that the risk of police detection is minimized. Incorporating drug transactions into kinship and friendship networks and reducing the number of customers and employees are two of the most frequent strategies that drug entrepreneurs employ to reduce their vulnerability to law enforcement efforts (Reuter, 1983, 1985; Moore, 1974, pp. 15-31). 


\section{Drug Trafficking in Russia}

These constraints have so far prevented the rise of large, hierarchically organized firms to mediate economic transactions in the illegal marketplace. The factors promoting the development of bureaucracies in the legal section of the economynamely the advantage deriving from economies of scale and the specialization of roles - are outbalanced in the illegal arena by the very consequences of product illegality. Due to these constraints, within the drug economy there is no immanent tendency towards the consolidation of large-scale, modern bureaucracies. In this respect at least - pace the much dreaded Mafya - Russia is no exception.

\section{Note on Interview Code}

All interviews with Russian and foreign law enforcement officers, public drug treatment providers, staff of drug-related NGOs, scholars as well as drug users themselves are kept anonymous and are referred to with a code (for example A1 or D5). The letter of the code refers to the specific background of the interviewee. In particular, A stays for Russian law enforcement officials; B for foreign law enforcement officers (including liaison officers interviewed in Moscow as well as several others interviewed abroad); C refers to Russian narcologists and state drug treatment providers; D to the staff of Russian and foreign drug-related NGOs; E to Russian and foreign academic scholars; F to Russian and foreign journalists; $G$ to the representatives of international organizations and $\mathrm{H}$ to drug users. Finally, to distinguish interviews with people of the same category, a progressive number has been added according to the interview's date. 


\section{REFERENCES}

Adler, PA.

1993 Wheeling and dealing. An ethnography of an upper-level drug dealing and smuggling community. New York: Columbia University Press.

AFP, Agence France Presse

2000 More drugs found in tajik embassy in kazakhstan scandal. May 23, at www.russiatoday.com.

Amnesty International

1999 Russian Federation (Chechnya): For the motherland, December.

Babajan, E.A.

1998 Primiecanja [Note]. Bjuletin verchovnego suda rossiskoj federacji, 4, 19. Bäckmann, J.

1998 The inflation of crime in Russia. The social danger of the emerging markets. Helsinki: National Research Institute of Legal Policy.

BBC Monitoring

2000 Chechen drugs ring busted in Siberia, June 2, at http://www.russiatoday.com Block, A., \& Chambliss, W.J.

1981 Organizing crime. New York and Oxford: Elsevier.

Brednikova, O., Cikadze, E., \& Snisarenko, A.

1997 'Armenisches leben' in St. Petersburg. Entstehung und entwicklung einer armenischen diaspora-gemeinde. In I. Oswald \& V. Voronkov (Eds.), Postsowjetische ethnizitäten. Ethnische gemeinden in St. Petersburg und Berlin/ Potsdam (pp. 55-73). Berlin: Berliner Debatte.

Butler, W.

1997 Criminal code of the Russian Federation. London: Simmonds and Hill. Ciklauri, E.

2000 Die drogenproblematik in der region nord-kaukasus unter besonderer berücksichtigung der republiknordossetien-alania, unpublished document.

Crowe, D.M.

1994 A history of the gypsies of Eastern Europe and Russia. New York: St. Martin's Press.

District Court of Moscow

1998 Sentence against Kurbanov S.G. and Three Others, December 10.

Dolgopjatova, T., Simacev, J., Tambovcev, V., \& Jakovlev, A.

1999 Schattenwirtschaft in Russland. Aktivitäten illegaler russischer unternehmen, No. 37/1999. Köln: Bundesinstitut für ostwissenschaftliche und internationale Studien.

Dragan, G.N. \& Kalacev, B.F.

1998 Narkomania l narkobisnes. Vyjavlienie I presjedcenie nezakonnogo oborota narkoticeskich sredstc I psychotropnych vescestv [Drug addiction and narco-business. Detecting and preventing illegal trafficking of narcotics and psychotropic substances]. Moscow. 


\section{Drug Trafficking in Russia}

Dunn, G.

1997 Major mafia gangs in Russia. In P. Williams (Ed.), Russian organized crime: The new threat? (pp. 63-88). London: Frank Cass.

Franchetti, M.

1998 Russian grannies sell their drugs. Sunday Times, January 25, at http://

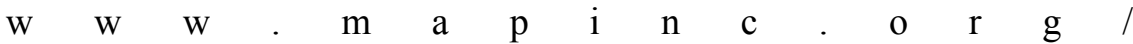
drugnews.

FSB, Federal Security Service

2000 Obsor narkosituazii na territorii Rossijskoj Federazii v $1999 \mathrm{~g}$ [Review of the drug situation on the territory of the Russian Federation in 1999], unpublished document.

FSB-North Ossetia, Federal Security Service of the Republic North Ossetia-Alanja 1998 "Tesisi doklada nachalnika Ypravlenija FSB RF po RSO - Alanija generalmajora Besyglogo V.F. [Hearing of the Head of the FSB Besyglov V. F.]. In Parliament of the Republic North Ossetia-Alanja (Ed.), O neotlosnix merax po borbe $s$ rasprostranenijem narkomanii v respyblike Severnaja Osetija - Alanija [Parliamentary hearings on the necessary measures to stop the spread of drug use in the Republic of North Ossetia-Alanja]. Vladikavkaz.

Gilinsky, Y., Kostjukovsky, Y., \& Rusakova, M.

2000 Site report on drug markets, drug trafficking, and organized crime in St. Petersburg, unpublished document.

Glinkina, S.P.

1999 Russia's underground economy during the transition. In E.G. Feige \& K. Ott (Eds.), Underground economies in transition: Unrecorded activity (pp. 101-116). Aldershot: Ashgate.

Goldenberg, S.

1994 Pride of small nations: The caucasus and post-Soviet disorder. London: Zed.

Halbach, U.

1999 Migration. Vertreibung und flucht im kaukasus. Ein europäisches problem. No. 13/1999. Köln: Bundesinstitut für ostwissenschaftliche und internationale Studien.

Hagan, F.

1983 The organized crime continuum: A further specification of a new conceptual model. Criminal Justice Review, 8, Spring, 52-57.

Handelman, S.

1995 Comrade criminal. Russia's new mafyia. New Haven: Yale University Press. 
PAOLI

Hille, S.

2000 In der hauptstadt des feindes. Zeitung zum Sonntag, October 1, p. 6.

Kichanov, M.V.

1999 Statement made at the meeting on the project 'Database for CIS States and Assessment of Organised Crime in the Russian Federation'. Vienna: UNODCCP, October 1.

Human Rights Watch

1995 Russia: Crime or simply punishment? Racist attacks by Moscow law enforcement. 7(12).

Hunter, S.

1997 Azerbaijan: Searching for New Neighbours. In I. Bremmer \& R. Taras (Eds.), New states, new politics: Building the post-Soviet nations (pp. 437470). Cambridge: Cambridge University Press.

Kniagininsky District Court of Nizhniy Novgorod

1999 Sentence in the penal proceeding no. 4836, November 11.

Kuibyshevsky Federal Court of St. Petersburg

1999a Sentence in the penal proceeding no. 1-459, May 12.

1999a, Sentence in the penal proceeding no. 1-1412, October 12.

Kurbanov, R.

1999 Precarious future for an urban minority: Ethnic azeris in Russia. Behind the Breaking News, 1(5), December 14, at http://www.bu.edu/iscip.

Lammich, S.

2000 Das russische Betäubungsmittelrecht unter besonderer Berücksichtigung der strafrechtlichen Regelung, unpublished manuscript.

Leninsky District Court of Krasnodar

1997 Sentence in the penal proceeding no. 38286, December 9.

1999 Sentence in the penal proceeding no. 76975, November 15.

Leninsky District Court of Omsk

1999 Sentence in the penal proceeding no. 15-555m-98-552081, July 12.

Maiorova, L.

2000 Potreblenije, torgovla narkotikami i organisovannaja prestypnost $v$ Krasnojarske [Drug use, drug trafficking and organised crime in Krasnoyarsk], unpublished document.

Markoryan, L.

2000 Potreblenije i torgovla narkotikami v Balakovo [Drug use and drug trafficking in Balakovo], unpublished document.

Ministero dell'Interno

1993 Rapporto annuale sul fenomeno della criminalità organizzata per il 1992. Roma. 
Moore, M.H.

1974 The effective regulation of an illicit market in heroin. Lexington: Lexington Books.

Morvant, P.

1996 Drug Market Expands in Russia. Transition, 2(19), 19-23.

Moscovsky District Court of Nizhniy Novgorod

1999, Sentence in the penal proceeding no. 62215, November 2.

MVD, Ministry of the Interior

1998a Kommentarii UK RF, Nezakonnyj oborot narkotikov [Commentary to the criminal code of the Russian Federation: Illegal circulation of narcotic drugs]. Rossijskaja Justizia, 1, 17-19.

1998b Kommentarii UK RF, Nezakonnyj oborot narkotikov [Commentary to the criminal code of the Russian Federation: Illegal circulation of narcotic drugs] Rossijskaja Justizia, 2, 12-14.

1998c Kommentarii UK RF, Nezakonnyj oborot narkotikov [Commentary to the criminal code of the Russian Federation: Illegal circulation of narcotic drugs] Rossijskaja Justizia, 3, 12-13.

2000 Kontrol sa narkotikami i predypresdenie prestypnosti v Rossijskoj Federazii. Organisovannaja prestypnost $i$ nesakonnij oborot narkotikov $v$ Rossijskoj Federazii [Drug control and crime prevention in the Russian Federation. Organised crime and illicit drug trafficking in the Russian Federation]. Moscow.

MVD-North Ossetia-Alanja, Ministry of the Interior of the Republic North OssetiaAlanja

1998 "Tesisi doklada Ministra vnytrennix del RSO-Alanija Dsantijev K. B." [Hearing of the Minister of the Interior], in Parliament of the Republic North Ossetia-Alanja (Ed.), O neotlosnix merax po borbe $s$ rasprostranenijem narkomanii v respyblike Severnaja Osetija - Alanija [Parliamentary hearings on the necessary measures to stop the spread of drug use in the Republic of North Ossetia-Alanja]. Vladikavkaz.

2000 Report on the drug situation in the Republic of North Ossetia-Alanja. Vladikavkaz.

Nizhniy Novgorod District Court

1998, Sentence in the penal proceeding no. 51111, November 18.

Obidina, L.

2000 Potreblenije, torgovla narkotikami i organisovannaja prestypnost v Nizni Novgorod [Drug use, drug trafficking and organised crime in Nizhniy Novgorod], unpublished document.

OGD Observatoire Géopolitique des Drogues,

2000 The world geopolitics of drugs 1998/1998. April, at http://www.ogd.org/. 
Paoli, L.

1999a Organised crime: Criminal organisations or the organisation of crime?". In H.-J. Albrecht (Ed.), Forschungen zu kriminalität und kriminalitätskontrolle am Max-Planck-Institut für ausländisches und internationales strafrecht (pp. 135-173). Freiburg: Edition Iuscrim.

1999b Die italienische mafia: Paradigma oder spezialfall der organisierten kriminalität?. Monatsschrift für Kriminologie und Strafrechtsreform, 6, 425440.

2000a (in co-operation with N. Güller \& S. Palidda), Pilot project to describe and analyse local drug markets: Illegal drug markets in Frankfurt and MilanFirst-phase final project, at http://www.emcdda.org.

2000b Fratelli di mafia: Cosa nostra e 'Ndrangheta. Bologna: Il Mulino.

2000c Qualitative methodology at the edge: Assessing Italian mafia groups' involvement in drug trafficking. In J. Fountain (Ed.), Understanding and responding to drug use: The role of qualitative research (pp. 191-196). Luxembourg: Office for Official Publications of the European Communities.

2001a Illegal drug trade in Russia. A research project commissioned by the United Nations Office for drug control and crime prevention. Freiburg: edition iuscrim.

$2001 \mathrm{~b}$ The paradoxes of organized crime. Crime, law and social change, forthcoming.

Petrograd District Court of St. Petersburg

1999a Sentence in the penal proceeding no. 1-609, April 4.

1999b Sentence in the penal proceeding no. 1-937, August 19.

1999c Sentence in the penal proceeding no. 1-432, August 31.

1999d Sentence in the penal proceeding no. 1-459, October 8.

Rakitsky, G.

2000 Potreblenije $i$ torgovla narkotikami v Khabarovsk [Drug use and drug trafficking in Khabarovsk], unpublished document.

Reuter, P.

1983 Disorganized crime. The economics of the visible hand, Cambridge: The MIT Press.

1985 The organization of illegal markets: An economic analysis. Washington: National Institute of Justice.

Reuter, P., \& Haaga, J.

1989 The organization of high-level drug markets: An exploratory study. Santa Monica: Rand.

Reuters

2000 Kazakhs find heroin in Tajik ambassador's car, May 23, at http://www. russiatoday.com. 
RIMVD, Research Institute of the Russian Ministry of the Interior

2000 Etnitsheskije grypi i nesakonnaja torgovla narkotikami [Ethnic groups and illicit drug trafficking], unpublished document.

RIPGO, Research Institute of the Prosecutor General's Office

2000 Report on the drug situation in the Russian Federation, Moscow, unpublished document.

Rosner, L.

1995 The sexy Russian mafia. Criminal Organizations, 10(1), at http://

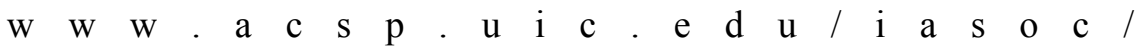
rosner.htm

Ryvkina, R.V.

1998 Economic sociology in Russia in the transition period. Delo, Moscow: Academy of the National Economy under the Russian Federation Government.

Saukhat, S.

2000 Potreblenije i torgovla narkotikami v Rostov [Drug use and drug trafficking in Rostov], unpublished document.

SCC, State Customs Committee of the Russian Federation

2000 Customs and drugs - 1999. Moscow.

Snisarenko, A.

1997 Die aserbaidschanische Gemeinde in St. Petersburg. Selbstbehauptung und Abwehrstrategien aserbaidschanischer Zuwanderer. In I. Oswald and V. Voronkov (Eds.), Post-sowjetische Ethnizitäten. Ethnische Gemeinden in St. Petersburg und Berlin/Potsdam (pp. 141-152). Berlin: Berliner Debatte. Sovietsky District Court of Krasnodar

1998 Sentence in the penal proceeding no. 17801, April 17.

1999a Sentence in the penal proceeding no. 96733, February 24.

1999b Sentence in the penal proceeding no. 97284, May 24.

Sovietsky District Court of Omsk

1999 Sentence in the penal proceeding no. 15-572-98-552098, February 19.

Standing Committee on Narcotic Drug Control

1998 Svodnaja Tablica zaklucenij postojannego komiteta po kontroliu narkotikov ob otnnesenii k nebolsim, krupnym i osobo krupnym razmieram kolicestv narkoticeskich sredstv, psychotropnych i silnodiejstvujuscich vescestv, obnaruzennych $\mathrm{v}$ nezakonnom chranieni ili oborotie [Note to the table summarising the decisions of the Standing Committee for Drug Control concerning small, large and especially large amounts of narcotic drugs, psychotropic substances and other psychoactive substances, which were detected in cases of illegal possession and sale]. Bjuletin Verchovnego Suda Rossiskoj Federacji, 4 (1999), 15-19. 
PAOLI

Tchernina, N.

1998 Die bevölkerung Rußlands in der transformationsphase. Soziale exklusion und adaptationstrategien. No. 27/1998. Köln: Bundesinstitut für ostwissenschaftliche und internationale Studien.

Tonshaevsky District Court of Nizhniy Novgorod

1999 Sentence in the penal proceeding no. 8852, November 15.

UNDP, United Nations Development Program

1999 Human development report 1999 - Russian Federation (edited by Y. Fedorov). Moscow: Human Rights Publishers.

Zavadskaya, Y.

2000 Potreblenije i torgovla narkotikami v Vladivostok [Drug use and drug trafficking in Vladivostok], unpublished document. 